\title{
Impact of Crr \& SLR and Investment on Loans and Advances of Sbi
}

\author{
Roshni Rawat \\ Ph.D Scholar in DAV College, Dheradun affiliated by HNB Garhwal University School of Commerce, Chauras \\ Campus, Srinagar, Uttarakhand
}

\begin{abstract}
The paper examines the impact of SLR, CRR and Investment on Loans and Advances of SBI. The study uses multiple regression analysis technique. Results suggested that CRR \& SLR having significant impact on Loans \& Advances and investment have negative insignificant impact on Loans \& Advances. The study period is $1^{\text {st }}$ April 2005 to $31^{\text {st }}$ March 2011 as the period is considered in which maximum volatility have been noticed in CRR and SLR.
\end{abstract}

\section{Cash Reserve Ratio}

\section{Introduction}

CRR was introduced in 1950 primarily as a measure to ensure safety and liquidity of bank deposits, however over the years it has become an important and effective tool for directly regulating the lending capacity of banks and controlling the money supply in the economy. When the RBI feels that the money supply is increasing and causing an upward pressure on inflation, the RBI has the option of increasing the CRR thereby reducing the deposits available with banks to make loans and hence reducing the money supply and inflation.

The reserve requirement (or cash reserve ratio) is a central bank regulation that sets the minimum reserves each commercial bank must hold (rather than lend out) of customer deposits and notes. It is normally in the form of cash stored physically in a bank vault (vault cash) or deposits made with a central bank.

The reserve ratio is sometimes used as a tool in the monetary policy, influencing the country's borrowing and interest rates by changing the amount of loans available. Western central banks rarely alter the reserve requirements because it would cause immediate liquidity problems for banks with low excess reserves; they generally prefer to use open market operations (buying and selling government-issued bonds) to implement their monetary policy. The People's Bank of China uses changes in reserve requirements as an inflation-fighting tool, ${ }^{[2]}$ and raised the reserve requirement ten times in 2007 and eleven times since the beginning of 2010. As of 2006 the required reserve ratio in the United States was $10 \%$ on transaction deposits and zero on time deposits and all other deposits.

The reserve requirement can affect monetary policy, because the higher the reserve requirement is set, the less money banks will have to loan out, leading to lower money creation, and maintaining the purchasing power of the currency previously in use. The effect is exponential, because money that is loaned out can be redeposited; a portion of that money may again be re-loaned, and so on. The effect on the monetary supply is governed by the following formula:

$$
\begin{aligned}
& M S=M b * m m \\
& m m=(1+c) /(c+R)
\end{aligned}
$$

$\mathrm{MS}=$ Money Supply

$\mathrm{Mb}=$ Monetary base

$\mathrm{mm}=$ money multiplier

$\mathrm{c}=$ rate at which people hold cash (as opposed to depositing it), equal to one minus marginal propensity to consume

$\mathrm{R}=$ the reserve requirement (the percent of deposits that banks are not allowed to lend)

However, in the United States (and other countries except Brazil, China, India, Russia), the reserve requirements are generally not frequently altered to affect monetary policy because of the exponential effect and the large time lag between the implementation of the change and the corresponding effects on inflation.

The present banking system is called a "fractional reserve banking system", as the banks are required to keep only a fraction of their deposit liabilities in the form of liquid cash with the central bank for ensuring safety and liquidity of deposits. The Cash Reserve Ratio (CRR) refers to this liquid cash that banks have to maintain with the Reserve Bank of India (RBI) as a certain percentage of their demand and time liabilities. For example if the CRR is $10 \%$ then a bank with net demand and time deposits of Rs 1,00,000 will have to deposit Rs 10,000 with the RBI as liquid cash. 


\section{Statutory Liquidity Ratio (SLR)}

Statutory Liquidity Ratio is the amount of liquid assets, such as cash, precious metals or other approved securities, that a financial institution must maintain as reserves other than the Cash with the Central Bank. The statutory liquidity ratio is a term most commonly used in India.

The objectives of SLR are:

1. To restrict the expansion of bank credit.

2. To augment the investment of the banks in Government securities.

3. To ensure solvency of banks. A reduction of SLR rates looks eminent to support the credit growth in India.

The SLR is commonly used to contain inflation and fuel growth, by increasing or decreasing it respectively. This counter acts by decreasing or increasing the money supply in the system respectively. Indian banks' holdings of government securities (Government securities) are now close to the statutory minimum that banks are required to hold to comply with existing regulation. When measured in rupees, such holdings decreased for the first time in a little less than 40 years (since the nationalization of banks in 1969) in 2005-06. While the recent credit boom is a key driver of the decline in banks' portfolios of G-Sec, other factors have played an important role recently.

These include:

1. Interest rate increases.

2. Changes in the prudential regulation of banks' investments in G-Sec.

Most G-Sec held by banks are long-term fixed-rate bonds, which are sensitive to changes in interest rates. Increasing interest rates have eroded banks' income from trading in G-Sec.

Recently a huge demand in G-Sec was seen by almost all the banks when RBI released around 108000 crore rupees in the financial system. This was by reducing CRR, SLR \& Repo rates. This was to increase lending by the banks to the corporate and resolve liquidity crisis. Providing economy with the much needed fuel of liquidity to maintain the pace of growth rate. However the exercise became futile with banks being over cautious of lending in highly shaky market conditions. Banks invested almost $70 \%$ of this money to rather safe Govt. securities than lending it to corporate.

The quantum is specified as some percentage of the total demand and time liabilities ( i.e. the liabilities of the bank which are payable on demand anytime, and those liabilities which are accruing in one months time due to maturity) of a bank.

SLR Rate $=$ Total Demand/Time Liabilities $\times 100 \%$

This percentage is fixed by the central bank. The maximum and minimum limits for the SLR are $40 \%$ and 25\% respectively in India. Following the amendment of the Banking regulation Act (1949) in January 2007, the floor rate of $25 \%$ for SLR was removed.

\section{Investments}

Investment has different meanings in finance and economics. In Finance investment is putting money into something with the expectation of gain, that upon thorough analysis, has a high degree of security of principle, as well as security of return, within an expected period of time. In contrast putting money into something with an expectation of gain without thorough analysis, without security of principal, and without security of return is speculation or gambling.

The every bank make investments in various activities such as, Govt. securities and \% corporate securities but mostly bank invest at least $70 \%$ of his deposit into the safe Govt. securities rather then investing in volatile corporate securities As the investments of bank get reduced then banks will offer more loans and advances and voice versa.

\section{Loans And Advances}

A loan is a type of debt. Like all debt instruments, a loan entails the redistribution of financial assets over time, between the lender and the borrower.

In a loan, the borrower initially receives or borrows an amount of money, called the principal, from the lender, and is obligated to pay back or repay an equal amount of money to the lender at a later time. Typically, the money is paid back in regular installments, or partial repayments; in an annuity, each installment is the same amount.

The loan is generally provided at a cost, referred to as interest on the debt, which provides an incentive for the lender to engage in the loan. In a legal loan, each of these obligations and restrictions is enforced by contract, which can also place the borrower under additional restrictions known as loan covenants. 
The SBI offer Loans and advances to various sectors but our study involves the Loans and the Advances offered for non banking financial institutes, financial institutes, banks and housing finance.

\section{Literature Review}

Importance

Firstly, related knowledge helps the investigator to avoid overlapping and it acquaints his with the level and the nature of research already done \& it indicated what remain to be done.

Secondly it helps the investigator to built up new edifice on the bases of perceive knowledge and the quality standard can be maintained or raised by keeping in view the previous qualities standards.

Thirdly related knowledge of the past studies are helpful for further development of any research work, so there is a dire need for an investigator to review the related literature.

Based on following review the study proposed the follow by:

David Korten 2009 : claim that fractional-reserve banking, by expanding the money supply, will lower the interest rates compared to a hypothetical full-reserve banking system, although this idea has been criticized within mainstream economics and increase the Loans and advances.

RBI (Amd.) Bill 2006: has been enacted and has come into force with its gazette notification consequent upon and to subsection to 42 (1), the RBI having regard to the needs of securing the monitory stability in the country can resemble CRR for scheduled banks without any floor rate or ceiling rate.

According to Mankiw, N. Gregory (2002), "Repeated bank failures and financial crises led to the creation of central banks - public institutions that have the authority to regulate commercial banks, impose reserve requirements, and act as lender-of-last-resort if a bank runs low on liquidity. The emergence of central banks mitigated the dangers associated with fractional reserve banking.

Merrih Uctum and Michael Wickens 1989: Concluded in his study that bank has to finance investments entirely from Bank Loans. Loans are used to invest in physical capital to produced domestic outputs.

Macmillan report 1931: Government regulations may also be used to limit the money creation process by preventing banks from giving out loans even though the reserve requirements have been fulfilled.

William Mac Eachern 1929: Concluded that The money multiplier, $m$, is the inverse of the reserve requirement, R. This multiplier number is multiplied by the initial deposit to show the maximum amount of money it can be expanded to Loans and Advances.

Joseph Schumpeter and post-Keynesians in $19^{\text {th }}$ Century: Their Endogenous money theory states that the supply of money is credit-driven and determined endogenously by the demand for bank loans, rather than exogenously by monetary authorities.

\section{Objective Of The Study}

The objective of this study is to evaluate the impact of Cash reserve ratio, statuary liquidity ratio and investment on the loans and advances of State Bank of India.

\section{Hypotheses Of The Study}

H01. There has no significant impact of CRR on Loans and Advances.

H02. There has no significant impact of SLR on Loans and Advances.

H03. There has no significant impact of Investments on Loans and Advances.

As CRR \& SLR are important quantitative instruments of monetary policy of RBI for credit control. And investment have some impact on Loans and Advances, but there has been a limited research on measuring the impact of CRR, SLR and investments by banks on Loans and Advances so, the present paper's aim is to filling out this gap.

\section{Research Design}

\section{Sample design and period of the study:}

The sample was based primarily on the data collected from the prowess data base of the center for monitoring the Indian economy (CMIE) SBI has been selected for the perpose of the study. The period is from 
$31^{\text {st }}$ march 2005 to $31^{\text {st }}$ March 2011. This was the most recent slot period during which maximum changes occurred in CRR and SLR.

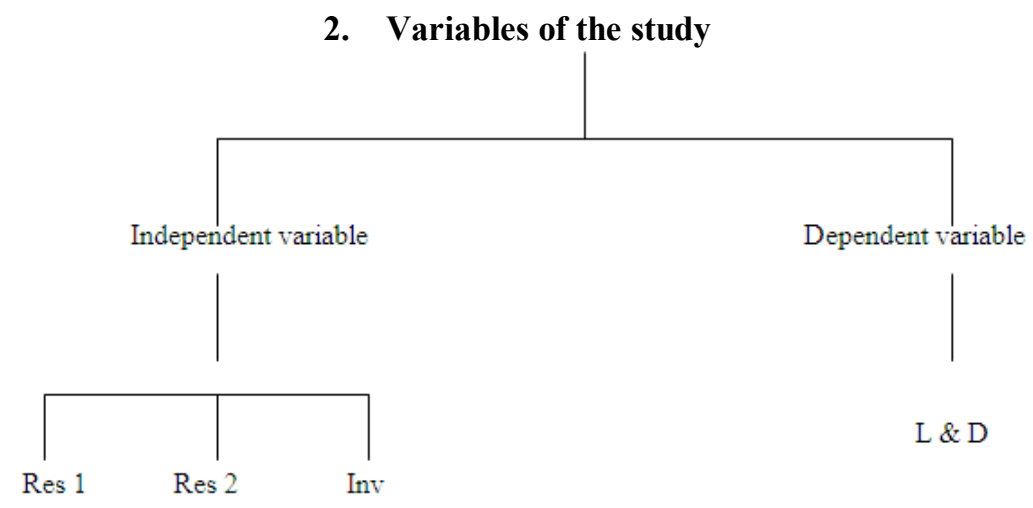

Res $1=$ Reserved based on CRR

Res $2=$ Reserve based on SLR

Inv $=$ Investments

L\&A = Loans and Advances (nbfcs/ banks/ fis / housing finance companies).

Multiple regression equation:-

$\mathrm{L} \& \mathrm{D}=\mathrm{a}+\mathrm{b} 1$ Res $1+\mathrm{b} 2$ Res $2+\mathrm{b} 3$ inv

\section{Emperical Results:}

Descriptive Statistics

\begin{tabular}{|l|l|l|l|}
\hline & Mean & Std. Deviation & N \\
\hline Loans & 449916.6971 & $2.02592 \mathrm{E} 5$ & 7 \\
SLR & 320467.8762 & $4.54616 \mathrm{E} 5$ & 7 \\
CRR & 71600.9281 & $1.46375 \mathrm{E} 5$ & 7 \\
Investments & 223660.2900 & 63603.95600 & 7 \\
\hline
\end{tabular}

Model Summary

\begin{tabular}{|c|c|c|c|}
\hline Model & $\mathrm{R}$ & R Square & Durbin- Watson \\
\hline 1 & $.982^{\mathrm{a}}$ & .964 & 2.452 \\
\hline
\end{tabular}

a. Predictors: (Constant), Investmants, SLR, CRR

b. Dependent Variable: Loans

Independent variable investments, SLR, CRR of the dependent variable having R square .964 is being explained by regression model. The value of Durbin Watson is 2.4 which is close to 2 , so that showing very little auto correlation.

$96.4 \%$ of variation is independent variable is explained $\mathrm{R}$ square $=96 \%$ by regression equations.

ANOVA $^{\mathrm{b}}$

\begin{tabular}{|ll|r|r|r|r|r|}
\hline Model & Sum of Squares & df & Mean Square & \multicolumn{1}{c|}{ F } & \multicolumn{1}{c|}{ Sig. } \\
\hline 1 & Regression & $2.375 \mathrm{E} 11$ & 3 & $7.915 \mathrm{E} 10$ & 26.988 & $.011^{\mathrm{a}}$ \\
& Residual & $8.799 \mathrm{E} 9$ & 3 & $2.933 \mathrm{E} 9$ & & \\
& Total & $2.463 \mathrm{E} 11$ & 6 & & & \\
\hline
\end{tabular}

a. Predictors: (Constant), Investmants, SLR, CRR

b. Dependent Variable: Loans

If $\mathrm{F}$ value is greater then 1 , then it will be fit for the study and in case of our study the value of $\mathrm{F}$ is greater then 1 so this model is fit for our study. 


\begin{tabular}{|ll|l|l|l|l|l|}
\hline \multicolumn{2}{|c|}{} & \multicolumn{2}{|c|}{ Coefficients $^{\text {a }}$} \\
\cline { 3 - 8 } Model & & Unstandardized Coefficients & $\begin{array}{l}\text { Standardized } \\
\text { Coefficients }\end{array}$ & \multicolumn{2}{l|}{} \\
\cline { 3 - 7 } & B & Std. Error & Beta & $\mathrm{t}$ & Sig. \\
\hline & (Constant) & 617071.385 & 232468.538 & & 2.654 & .077 \\
& SLR & 5.695 & 1.472 & 12.779 & 3.868 & .031 \\
& CRR & -17.998 & 4.709 & -13.004 & -3.822 & .032 \\
& Investmants & -3.145 & 1.608 & -.988 & -1.956 & .145 \\
\hline
\end{tabular}

a. Dependent Variable: Loans

As $b$ values of SLR and CRR are significant at $P<0.05$, there is a significant relation of these value and as $b$ value of investment is negative insignificant at $p<0.05$, there is a negative insignificant relation of this value.

\section{Conclusion}

The present study relates to the impact of CRR \& SLR on loans \& advances and investments of SBI. The results shows that there is the significant impact of Cash Reserve Ratio (CRR) and Statuary Liquidity Ratio (SLR ) on the loans \& advances and impact of investment on Loans and Advances of SBI within the period from 2005-2011.

\section{Scope for Further Study}

The study can involve the more larger period and also the other banks also so that the study can done through the time series analysis and also cross sectional analysis and helpful in comparative study so that the study becomes more reliable.

[1]. Duguid,charles, The stock exchange (1904)

\section{Refrences}

[2]. Wacha, D.E,A Financial chapter in the history of bomby city (1910)

[3]. Einzig,Paul,World Finance since 1914 ( London, 1935)

[4]. Sonari,V.N, Post war inflation in India (1949)

[5]. Sing, V.B.,Economic History of INDIA 1857-1956(ALLIED Publisher Pvt Ltd, Bombay, 19650

[6]. Simha,S.L.N,The capital market of India ( Vora \&co, Publishers Pvt. Ltd 1986)

[7]. David Korten 2009

[8]. RBI (Amd.) Bill 2006

[9]. Mankiw, N. Gregory (2002)

[10]. Merrih Uctum and Michael Wickens 1989

[11]. Macmillan report 1931

[12]. Joseph Schumpeter and post-Keynesians in $19^{\text {th }}$ Century

[13]. Website: http:/indiabudget.nic. 